\title{
ROLE OF CBC PARAMETERS IN COPD WITH ACUTE EXACERBATION IN A TERTIARY CARE GENTER
}

\author{
Pudasaini $\boldsymbol{S}^{1}$, Adhikari $P^{2}$, Maharjan $\boldsymbol{S}^{1}$, Jha $A K^{2}$, Dhakal $N^{3}$
}

${ }^{1}$ Department of Pathology, ${ }^{2}$ Department of Medicine, ${ }^{3}$ Department of Community Medicine, Nepal Medical College Teaching Hospital, Attarkhel, Gokarneshwor-8, Kathmandu, Nepal

\begin{abstract}
Chronic obstructive pulmonary disease (COPD) is a major global health problem. It is a complex disease characterised by chronic inflammation in the airways by noxious particles. Episodes of increased symptoms called as acute exacerbations are associated with accelerated decline in the lung function. Blood cultures to find out the causative organism in these cases are time consuming. Complete Blood Count (CBC) parameters like Total leukocyte count (TLC), hemoglobin (Hb), platelet count, Mean Platelet Volume (MPV), Platelet Distribution Width (PDW) are found to be related with COPD and its acute exacerbation. An observational hospital based descriptive study was conducted for a period of six months in the Department of Pathology and Medicine of a tertiary care centre. A total of 144 patients of COPD with acute exacerbation (AECOPD) were included in the study. The mean age of the patients was $70.47 \pm 9.49$ years with female preponderance $(61.1 \%)$. Though mean hemoglobin level (13.25 \pm 2.70 gm \%), (95\% CI 12.80-13.69) showed statistical significance, other CBC parameters had no obvious difference among the different groups of AECOPD patients. But we cannot deny on the clinical significance of these parameters. The TLC and platelet count were slightly lower in the AECOPD patients with cor pulmonale when compared with AECOPD patients without cor pulmonale. Similarly, platelet parameters like MPV and PDW were slightly higher in the AECOPD patients who are smokers. Though these parameters were not statistically significant, they are found to be cost effective, time saving and clinically significant which would definitely help in the management of AECOPD patients. Hence, these parameters can be used as an easily measurable AECOPD biomarker.
\end{abstract}

\section{KEYWORDS}

Chronic obstructive pulmonary

disease (COPD), acute

exacerbation, Complete blood

count (CBC), hemoglobin, platelet

count

\section{CORRESPONDING AUTHOR}

Dr. Sujata Pudasaini,

Associate Professor, Department of Pathology,

Nepal Medical College Teaching Hospital,

Gokarneshwor-8, Kathmandu, Nepal

Email: sujatapudasaini@gmail.com

ORCID ID: 0000-0001-9699-8204

DOI: https://doi.org10.3126/nmcj.v21i4.27627 


\section{INTRODUCTION}

Chronic obstructive pulmonary disease (COPD) is a complex and heterogenous disease characterised by chronic inflammation in the airways by noxious particle such as tobacco smoking. ${ }^{1}$ Chronic obstructive pulmonary disease is a major global health problem with an upward trend. ${ }^{2}$ It is characterised by progressive air flow limitation that is not fully reversible and is associated with an abnormal inflammatory response of the lung to noxious particles or gases. ${ }^{2,3}$

In some patients there are episodes of increased symptoms called as acute exacerbations. ${ }^{3}$ Acute exacerbations is clinically defined as increase in shortness of breathing, severity of cough and sputum volume and/or purulence of sputum. Acute exacerbation of COPD (AECOPD) have short and long term clinical implications and are associated with accelerated decline in lung function which is the hallmark of COPD. ${ }^{4}$

This contributes to disease severity and is implicated in the quality of life, morbidity and mortality of these patients. ${ }^{2}$ Assessment of COPD is based primarily on clinical presentations which can be variable and due to these, many biomarkers are also assessed. ${ }^{2,5}$ Blood culture has been commonly used as a traditional approach for the detection of any infectious cause. However, blood cultures are time consuming and it takes days to weeks to identify the bacterial or fungal organism in the blood. Blood analysis like Total leukocyte count (TLC) and neutrophil count are performed in all exacerbation cases and have a limited value in the early detection of community acquired bacteremia. ${ }^{5}$ The search therefore continues for additional infection markers that may facilitate the prediction of bacteremia. Although new markers (procalcitonin and proadrenomedullin) are being evaluated, the swift implementation of these markers is hampered by validation, costs and accessibility. ${ }^{6}$

Elevation of TLC is seen in any other inflammatory conditions. ${ }^{1}$ From Complete blood count (CBC), different parameters can be measured and can be used for the evaluation of AECOPD. Red Cell Distribution Width (RDW) is a routine hemogram test which refers to the variation in size of erythrocytes. It is also considered as a prognostic factor in certain inflammatory conditions. ${ }^{7}$

Studies done in different parts of the world has shown the association of TLC, Hemoglobin ( $\mathrm{Hb})$, platelet count, Mean Platelet Volume (MPV), Platelet Distribution Width (PDW) and RDW with COPD..$^{7-10}$ This study was conducted to find out the role of CBC parameters in AECOPD. All the patients of AECOPD coming to Nepal Medical
College Teaching Hospital (NMCTH) were included in the study.

\section{MATERIALS AND METHODS}

An observational hospital based descriptive study was carried out in the Department of Pathology in collaboration with Department of Medicine of a tertiary care centre (NMCTH) for a period of six months (November 2018 to April 2019). Ethical approval was taken from Institutional Review Committee (IRC) of NMCTH. A total of 144 patients of AECOPD who are diagnosed clinically in Medicine Out Patient Department (OPD)/ Emergency (ER) was included in the study where the diagnosis of COPD was made based on Global Initiative for Chronic Obstructive Lung Disease (GOLD) guidelines.

After the written consent from the patient/ patient party, blood sample of patients from OPD, ward and ER patients was sent to the Clinical Lab. Sample which was collected in Ethylene diamine tetra acetic acid (EDTA) vial was run in Sysmex 5 parts hematology automatic cell counter- XS500i. The CBC parameters- TLC, Hb level, platelet count, MPV, PDW and RDW were obtained from the computer. Relevant clinical history of the patients was also taken. Patients less than 40 years, patient with bleeding disorder and hematological malignancies were excluded from the study.

Data were entered in Microsoft Excel 2003 and then analyzed by using (Statistical Package for Social Sciences) SPSS version 16. Mean age of the patients and sex wise distribution was reported. Mean of each variable was compared with sex and associated disease conditions like cor pulmonale and systemic diseases like hypertension, diabetes and renal failure. Variables were compared among COPD patients who are smokers and nonsmokers. The level of significance ( $\infty$ ) was set at $5.0 \%$ and $p$ value $<0.05$ was considered significant.

\section{RESULTS}

There were a total of 144 patients of AECOPD in this study. The age of the patient ranged from 43 years to 93 years with the mean age of 70.47 \pm 9.49 years. Females (61.1\%) with AECOPD were more in number compared to male (38.9\%). Mean age of male patients was $72.62 \pm 8.86$ years and mean age of female patients was $69.09 \pm 9.67$ years (Table 1).

Out of the total number of patients, 93 (64.58\%) of them were smokers. Cor pulmonale was seen in 62 patients (43.05\%) and other systemic diseases like hypertension, diabetes and renal failure was seen in 56 patients (38.89\%). 
Table 1: Sex wise distribution of AECOPD

\begin{tabular}{|lcccc|} 
& & \multicolumn{3}{c}{ Age (years) } \\
Sex & $\mathbf{n}$ & Mean \pm SD & Min & Max \\
Male & $56(38.9 \%)$ & $72.62 \pm 8.86$ & 50 & 95 \\
Female & $88(61.1 \%)$ & $69.09 \pm 9.67$ & 43 & 85 \\
\hline
\end{tabular}

Mean $\mathrm{Hb}$ level in male and female patients were $12.82 \pm 2.38 \mathrm{gm} \%$ and $13.52 \pm 2.87 \mathrm{gm} \%(95 \% \mathrm{CI}$ of mean difference, -1.61- 0.21 ) respectively. There was no significant difference in Hb level among male and female patients and in different groupsAECOPD with cor pulmonale, systemic diseases and AECOPD patients who were smokers (Table 2).

\begin{tabular}{|c|c|c|c|c|c|c|c|}
\hline \multirow{2}{*}{ Hb (gm\%) } & & \multirow{2}{*}{ Mean } & \multirow{2}{*}{$\begin{array}{l}\text { Standard } \\
\text { Deviation }\end{array}$} & \multirow{2}{*}{$\begin{array}{c}\text { Mean } \\
\text { Difference }\end{array}$} & \multicolumn{2}{|c|}{$\begin{array}{c}\text { 95\% CI of Mean } \\
\text { difference }\end{array}$} & \multirow{2}{*}{$P$ value } \\
\hline & & & & & $\begin{array}{l}\text { Upper } \\
\text { limit }\end{array}$ & Lower limit & \\
\hline \multirow[t]{2}{*}{ Sex } & Male & 12.82 & 2.38 & \multirow{2}{*}{-0.70} & \multirow[t]{2}{*}{-1.61} & \multirow[t]{2}{*}{0.21} & \multirow[t]{2}{*}{0.129} \\
\hline & Female & 13.52 & 2.87 & & & & \\
\hline \multirow{2}{*}{$\begin{array}{l}\text { Cor } \\
\text { Pulmonale } \\
\text { (CP) }\end{array}$} & Absent & 12.95 & 2.68 & \multirow[b]{2}{*}{0.70} & \multirow[b]{2}{*}{-0.19} & \multirow[b]{2}{*}{1.60} & \multirow[b]{2}{*}{0.123} \\
\hline & Present & 13.65 & 2.70 & & & & \\
\hline \multirow{2}{*}{$\begin{array}{l}\text { Other } \\
\text { Systemic } \\
\text { Disease }\end{array}$} & Absent & 13.55 & 2.84 & \multirow[b]{2}{*}{-0.78} & \multirow[b]{2}{*}{-1.69} & \multirow[b]{2}{*}{0.12} & \multirow[b]{2}{*}{0.090} \\
\hline & Present & 12.77 & 2.41 & & & & \\
\hline \multirow[t]{2}{*}{ Smoker } & Yes & 13.56 & 2.75 & \multirow[t]{2}{*}{0.89} & \multirow[t]{2}{*}{-0.03} & \multirow[t]{2}{*}{1.81} & \multirow[t]{2}{*}{0.059} \\
\hline & No & 12.68 & 2.54 & & & & \\
\hline
\end{tabular}

\section{Table 3: Comparison of TLC in different groups}

\begin{tabular}{|c|c|c|c|c|c|c|c|}
\hline \multirow{2}{*}{$\begin{array}{l}\text { TLC } \\
\left(\times 10^{3} / \mu \mathrm{l}\right)\end{array}$} & & \multirow{2}{*}{ Mean } & \multirow{2}{*}{$\begin{array}{l}\text { Standard } \\
\text { Deviation }\end{array}$} & \multirow{2}{*}{$\begin{array}{l}\text { Mean } \\
\text { Difference }\end{array}$} & \multicolumn{2}{|c|}{$\begin{array}{l}\text { 95\% CI of Mean } \\
\text { difference }\end{array}$} & \multirow{2}{*}{$P$ value } \\
\hline & & & & & $\begin{array}{l}\text { Upper } \\
\text { limit }\end{array}$ & $\begin{array}{l}\text { Lower } \\
\text { limit }\end{array}$ & \\
\hline \multirow{2}{*}{ Sex } & Male & 11.12 & 5.10 & \multirow[t]{2}{*}{1.77} & \multirow[t]{2}{*}{0.25} & \multirow[t]{2}{*}{3.29} & \multirow[t]{2}{*}{0.023} \\
\hline & Female & 9.35 & 4.07 & & & & \\
\hline \multirow{2}{*}{$\begin{array}{l}\text { Cor } \\
\text { Pulmonale } \\
\text { (CP) }\end{array}$} & Absent & 11.71 & 4.97 & \multirow{2}{*}{-3.88} & \multirow{2}{*}{-5.26} & \multirow{2}{*}{-2.50} & \multirow{2}{*}{0.000} \\
\hline & Present & 7.83 & 2.69 & & & & \\
\hline \multirow{2}{*}{$\begin{array}{l}\text { Other } \\
\text { Systemic } \\
\text { Disease }\end{array}$} & Absent & 9.52 & 4.30 & \multirow[b]{2}{*}{1.32} & \multirow[b]{2}{*}{-0.21} & \multirow[b]{2}{*}{2.85} & \multirow[b]{2}{*}{0.090} \\
\hline & Present & 10.85 & 4.87 & & & & \\
\hline \multirow{2}{*}{ Smoker } & Yes & 9.90 & 4.52 & \multirow{2}{*}{-0.38} & \multirow{2}{*}{-1.95} & \multirow{2}{*}{1.20} & \multirow{2}{*}{0.638} \\
\hline & No & 10.28 & 4.68 & & & & \\
\hline
\end{tabular}

\section{Table 4: Comparison of platelet count in different groups}

\begin{tabular}{|c|c|c|c|c|c|c|c|}
\hline \multirow{2}{*}{$\begin{array}{l}\text { Platelet count } \\
\left(\mathrm{x} 10^{3} / \mu \mathrm{l}\right)\end{array}$} & & \multirow{2}{*}{ Mean } & \multirow{2}{*}{$\begin{array}{l}\text { Standard } \\
\text { Deviation }\end{array}$} & \multirow{2}{*}{$\begin{array}{c}\text { Mean } \\
\text { Difference }\end{array}$} & \multicolumn{2}{|c|}{ 95\% CI of Mean difference } & \multirow{2}{*}{$\begin{array}{c}P \\
\text { value }\end{array}$} \\
\hline & & & & & Upper limit & Lower limit & \\
\hline \multirow{2}{*}{ Sex } & Male & 225.59 & 81.26 & \multirow{2}{*}{12.62} & \multirow{2}{*}{-12.77} & \multirow{2}{*}{38.01} & \multirow{2}{*}{0.327} \\
\hline & Female & 212.97 & 70.99 & & & & \\
\hline \multirow{2}{*}{ Cor Pulmonale } & Absent & 233.77 & 78.03 & \multirow{2}{*}{-36.91} & \multirow{2}{*}{-61.24} & \multirow{2}{*}{-12.59} & \multirow{2}{*}{0.003} \\
\hline & Present & 196.85 & 66.01 & & & & \\
\hline \multirow{2}{*}{$\begin{array}{l}\text { Other Systemic } \\
\text { Disease }\end{array}$} & Absent & 213.66 & 70.09 & \multirow{2}{*}{10.84} & \multirow{2}{*}{-14.57} & \multirow{2}{*}{36.25} & \multirow{2}{*}{0.400} \\
\hline & Present & 224.50 & 82.64 & & & & \\
\hline \multirow{2}{*}{ Smoker } & Yes & 215.39 & 68.51 & \multirow{2}{*}{-7.02} & \multirow{2}{*}{-32.97} & \multirow{2}{*}{18.92} & \multirow{2}{*}{0.593} \\
\hline & No & 222.41 & 86.44 & & & & \\
\hline
\end{tabular}


Table 5: Comparison of MPV in different groups

\begin{tabular}{|llcccccc} 
MPV (fL) & & Mean & $\begin{array}{c}\text { Standard } \\
\text { Deviation }\end{array}$ & $\begin{array}{c}\text { Mean } \\
\text { Difference }\end{array}$ & $\begin{array}{c}\text { 95\% CI of Mean difference } \\
\text { Upper limit }\end{array}$ & Lower limit & Palue \\
Sex & Male & 10.57 & 1.38 & & & & \\
& Female & 10.49 & 1.25 & 0.09 & -0.35 & 0.53 & 0.701 \\
Cor Pulmonale & Absent & 10.64 & 1.28 & & & & \\
& Present & 10.36 & 1.31 & -0.28 & -0.71 & 0.15 & 0.196 \\
Other Systemic & Absent & 10.63 & 1.40 & & & & \\
Disease & Present & 10.34 & 1.11 & -0.29 & -0.73 & 0.15 & 0.190 \\
Smoker & Yes & 10.73 & 1.43 & & & & \\
& No & 10.14 & 0.92 & 0.58 & 0.15 & 1.02 & 0.009 \\
\hline
\end{tabular}

\section{Table 6: Comparison of PDW in different groups}

\begin{tabular}{|c|c|c|c|c|c|c|c|}
\hline \multirow{2}{*}{ PDW (\%) } & & \multirow{2}{*}{ Mean } & \multirow{2}{*}{$\begin{array}{l}\text { Standard } \\
\text { Deviation }\end{array}$} & \multirow{2}{*}{$\begin{array}{c}\text { Mean } \\
\text { Difference }\end{array}$} & \multicolumn{2}{|c|}{ 95\% CI of Mean difference } & \multirow{2}{*}{$\begin{array}{c}\mathbf{P} \\
\text { value }\end{array}$} \\
\hline & & & & & Upper limit & Lower limit & \\
\hline \multirow{2}{*}{ Sex } & Male & 12.16 & 2.78 & \multirow{2}{*}{-0.16} & \multirow{2}{*}{-1.06} & \multirow{2}{*}{0.74} & \multirow{2}{*}{0.720} \\
\hline & Female & 12.33 & 2.58 & & & & \\
\hline \multirow{2}{*}{ Cor Pulmonale } & Absent & 12.55 & 2.92 & \multirow{2}{*}{-0.65} & \multirow{2}{*}{-1.53} & \multirow{2}{*}{0.23} & \multirow{2}{*}{0.144} \\
\hline & Present & 11.89 & 2.21 & & & & \\
\hline \multirow{2}{*}{$\begin{array}{l}\text { Other Systemic } \\
\text { Disease }\end{array}$} & Absent & 12.43 & 2.78 & \multirow{2}{*}{-0.42} & \multirow{2}{*}{-1.32} & \multirow{2}{*}{0.48} & \multirow{2}{*}{0.356} \\
\hline & Present & 12.01 & 2.44 & & & & \\
\hline \multirow{2}{*}{ Smoker } & Yes & 12.72 & 2.89 & \multirow{2}{*}{1.28} & \multirow{2}{*}{0.39} & \multirow{2}{*}{2.17} & \multirow{2}{*}{0.005} \\
\hline & No & 11.44 & 1.92 & & & & \\
\hline
\end{tabular}

\section{Table 7: Comparison of RDW in different groups}

\begin{tabular}{|lllccccc} 
RDW (\%) & & Mean & $\begin{array}{c}\text { Standard } \\
\text { Deviation }\end{array}$ & $\begin{array}{c}\text { Mean } \\
\text { Difference }\end{array}$ & $\begin{array}{c}\text { 95\% CI of Mean difference } \\
\text { Upper limit }\end{array}$ & $\begin{array}{c}\text { Power limit } \\
\text { value }\end{array}$ \\
& Male & 15.04 & 1.87 & -0.42 & -1.35 & 0.51 & 0.369 \\
Cox Pulmonale & Absent & 14.93 & 2.64 & & & & \\
& Present & 15.78 & 2.84 & 0.85 & -0.05 & 1.76 & 0.065 \\
Other Systemic & Absent & 15.18 & 2.71 & & & & \\
Disease & Present & 15.47 & 2.82 & 0.29 & -0.64 & 1.22 & 0.539 \\
Smoker & Yes & 15.37 & 2.90 & & & & \\
& No & 15.15 & 2.48 & 0.22 & -0.73 & 1.17 & 0.644 \\
\hline
\end{tabular}

Mean TLC between male (11.12 x 10土 5.10) and female $\left(9.35 \times 10^{3} \pm 4.07\right)$ patients with $95 \%$ CI of mean difference, $0.25-3.29$ was found to be statistically significant. Similarly, there was significant difference in the mean TLC and platelet count among AECOPD patients with cor pulmonale and AECOPD patients without cor pulmonale. (Table 3 and 4)
The comparison of MPV and PDW among AECOPD patients with and without cor pulmonale, with and without systemic diseases and who were smokers and non smokers was shown in Table 5 and 6. Patients who were smokers had significantly higher level of MPV and PDW. The mean difference in RDW in AECOPD patients in different groups was not significant. (Table 7) 


\section{DISCUSSION}

This study showed the mean age of the patients with AECOPD was $70.47 \pm 9.49$ years where mean age of male patients was more than mean age of female patients. Females were found to be younger as compared to males in a study done by Jain et $a{ }^{11}{ }^{11}$ Milacic et $a l^{12}$ and Agapakis et $a l^{2}$ showed the mean age of $67.76 \pm 9.39$ and $65.3 \pm 11.1$ years respectively. In one study done in India, COPD patients were much younger where the mean age was $60.61 \pm 10.36$ years. ${ }^{11}$ Majority of the patients in our study were females. In contrast to our study, several other studies showed that AECOPD were more commonly seen in males., ${ }^{1,2,11-14}$ The gender difference was not significant in our study. Anecchino et al ${ }^{13}$ showed no gender difference in the occurrence of the disease before 75 years of age but the difference was evident in patients more than 75 years. Milacic et $a l^{12}$ also showed no gender difference in AECOPD. In a study done in India, it was observed that the gender related difference do exist in AECOPD patients. Increased tobacco use in women likely explains some of the increase in the prevalence of COPD in women but data suggests that women may actually be at greater risk of smoking induced lung function impairment and severe dyspnoea for the same level of tobacco exposure. Non smokers with AECOPD are more likely to be females. Evidence also suggests that men are more prone to emphysematous phenotype. ${ }^{15}$ Apart from tobacco smoke, the indoor air pollution from biomass fuel plays an important role in the development of COPD in women. ${ }^{11}$

Most of the patients were smokers (64.58\%) in our study like in other studies. ${ }^{11,12,14}$ Study has shown that smoking is a major factor in AECOPD and most smokers admitted for exacerbation of COPD were included in the severe COPD group. ${ }^{16}$ Cor pulmonale was seen in $43.05 \%$ patients in our study. Cardiac co morbidity like cor pulmonale increases with the severity of AECOPD. Kaushal et $a l^{17}$ found that $32 \%$ of COPD patients in their study had cor pulmonale. Cor pulmonale can be seen as high as $79 \%$ in cases of AECOPD. ${ }^{18}$

Other systemic diseases like hypertension, diabetes and renal failure was seen in $38.89 \%$ patients. Studies have shown the coexisting illness like diabetes and hypertension in COPD as well as AECOPD patients.1,11,13,14 Diabetes among COPD was seen in $3.1 \%$ patients in a study done by Jain et al. ${ }^{11}$ Ittyachen et $a l^{14}$ also showed diabetes in $27.1 \%$ and hypertension in $28.6 \%$ of COPD patients. Koo et al ${ }^{1}$ showed coexisting diabetes in $18.0 \%$ and hypertension in $52.6 \%$ of COPD cases. In a study done by Anecchino et $a l^{13}$, diabetes was seen in $12.4 \%$ of COPD patients and cardiovascular disease $(64.4 \%)$ was the most common condition coexisting in COPD patients.

Anemia has been recognized as a frequent comorbidity in COPD patients. ${ }^{19,20}$ The prevalence of anemia in patients with COPD varies from $7.5 \%$ to $33 \%$. Anemia of chronic disease is probably the most common type of anemia associated with COPD. ${ }^{19}$ Male patients had mean Hb level slightly lower than the normal in our study. The difference in the $\mathrm{Hb}$ level was neither significant among male and female groups nor in other groups like AECOPD with cor pulmonale, systemic diseases and AECOPD patients who were smokers. Toft-Peterson et $a l^{21}$ also showed that male COPD patients had lower level of hemoglobin than female patients and concluded that low $\mathrm{Hb}$ were frequent in COPD patients with acute exacerbations.

Increased in TLC has been reported in COPD patients. ${ }^{1}$ Our study showed slightly higher mean TLC in male patients and normal TLC in female patients and the difference was statistically significant. Similar to our finding, Alkadi et $a l^{22}$ and Karadeniz et $a l^{8}$ also showed significant increase in TLC in AECOPD patients. Our study showed significant low TLC in AECOPD patients with cor pulmonale than AECOPD patients without cor pulmonale. Similar correlation with TLC, smoking and AECOPD severity was found in a study done by Koo et $a l^{1}$ in Korea.

Mean platelet count in AECOPD patients with cor pulmonale was comparatively less than the patients in other groups and the difference was significant in our study. Studies had shown significant increase in the platelet count in AECOPD. ${ }^{23,24}$ Platelet count, a commonly measured clinical assay, may be a biomarker for moderate-severe COPD symptoms. ${ }^{24}$ In contrast to this, Skoczynski et $a^{25}$ showed that COPD has no influence in the platelet count.

The MPV and PDW indicates the severity of inflammation as inflammation plays an important role in AECOPD. ${ }^{10}$ According to our study, there exists a statistical significance among smokers and non smokers AECOPD patients with respect to MPV and PDW. Studies conducted in different parts of the world had shown that MPV values were significantly lower in patients AECOPD. ${ }^{8,10,26-28}$ Ragulan et $a l^{10}$ explained that negative correlation occurs between MPV and severity of COPD. ${ }^{10}$ Cigarette smoking was proved to be associated with an increased MPV. ${ }^{28}$ This was supported by our finding which showed slightly higher MPV level in smoker COPD patients than 
the non smoker patients though it was within the normal range. In our study, PDW was within normal range which was similar to a study done by Ragulan et al. ${ }^{10}$ However, in a study done by Karadeniz et al, ${ }^{8}$ higher PDW was seen in AECOPD.

The mean RDW was slightly higher in our study but statistically no difference was identified with respect to different groups of AECOPD but finding of Ragulan et $a l^{10}$ showed statistical significance among male and female AECOPD with respect to RDW. In their study, RDW was higher in male which was in contrast to our study where female had a slightly higher RDW. Elevated RDW has been linked with inflammatory process of chronic disorders. It is a well known fact that inflammation causes deterioration in the erythrocyte membrane and reduces the lifespan of red cells. Studies had revealed that RDW significantly increases with COPD. ${ }^{7,29}$ It was also seen that RDW elevation becomes more prominent as the stage of COPD advanced. ${ }^{7}$
In conclusion, chronic obstructive pulmonary disease is quite common in our part of the world and acute exacerbations are very common. Though inflammatory markers are readily available, some are not cost-effective and other tests like culture takes time. Tests like $\mathrm{Hb}$, Platelet count, MPV, PDW and RDW is easily available while performing $\mathrm{CBC}$ in the coulter counter. These tests were associated with AECOPD and showed clinical significance in parameters like $\mathrm{Hb}$ among male and female patients and TLC and platelet count among patients with cor pulmonale and without cor pulmonale. Platelet parameters like MPV and PDW among smokers were slightly higher than non smokers AECOPD patients. Our study also showed that $\mathrm{CBC}$ counts were within the normal range and had weak statistical power. Based on our study, we can conclude that CBC parameters provide the additional information for treatment selection in AECOPD patients. Hence, these parameters can be considered as simple and convenient AECOPD biomarkers.

\section{REFERENCES}

1. Koo HK, Kang HK, Song P, Park HK, Lee SS, Jung H. Systemic white blood cell count as a biomarker associated with severity of chronic obstructive lung disease. Tuberc Respir Dis 2017; 80: 304-10.

2. Agapakis DI, Massa EV, Hantzis I et al. The role of mean platelet volume in chronic obstructive pulmonary disease exacerbation. Resp Care 2016; 61: 44-8.

3. Chhabra SK, Dash DJ. Acute exacerbations of chronic obstructive pulmonary disease: causes and impacts. Indian J Chest Dis Allied Sci 2014; 56: 93104.

4. Qureshi H, Sharafkhaneh A, Hanania NA. Chronic obstructive pulmonary disease excerbations: latest evidence and clinical implications. Ther $A d v$ Chronic Dis 2014; 5: 21-7.

5. Gallego M, Pomares X, Capilla $S$ et al. C reactive protein in outpatients with acute exacerbation of COPD; its relationship with microbial etiology and severity. Int'l J COPD 2016; 11: 2633-40.

6. De Jager CPC, Paul TLV Wijk, Mathoera RB, Jongh- Leuvenink JD, Poll TVD, Wever PC. Lymphocytopenia and neutrophil- lymphocyte count ratio predict bacteremia better than conventional infection markers in an emergency care unit. Crit Care 2010; 14: R192.

7. Kocak MZ. Evaluation of red cell distribution width levels during acute exacerbation in patients with chronic obstructive pulmonary disease. Biomed Res India 2017; 28: 3009-11.

8. Karadeniz G, Aktogu S, Erer OF, Bulac Kir S, Doruk S, Demir M. Evaluation of mean platelet volume and platelet distribution width in patients with chronic obstructive pulmonary disease. Eur Resp J 2015; 46:3984-7.
9. Kocak MZ. Analysis of mean platelet volume in chronic obstructive pulmonary disease patients during acute attack. Biomed Res India 2017; 28: 2783-5.

10. Ragulan R, Viswambhar V, Krishnaveni R et al. Evaluation of platelet indices among patients with exacerbation of COPD in a tertiary care center in South India. Int'l Arch Integr Med 2017; 4: 161-6

11. Jain NK, Thakkar MS, Jain N, Rohan KA, Sharma M. Chronic obstructive pulmonary disease: does gender really matter. Lung India 2011; 28: 258-62.

12. Milacic N, Milacic B, Milojkovic M et al. Correlation of $C$ reactive protein and COPD severity. Acta Clin Croat 2016; 55: 41-8.

13. Anecchino C, Rossi E, Fanizza C, De Rosa M, Tognono G, Romero M. Prevalence of chronic obstructive pulmonary disease and pattern of comorbidities in a general population. Int'l J COPD 2007; 2: 567-74.

14. Ittyachen AM, Krishnamoorthy S, Kuriakose J. Predictors of outcome in patients admitted with acute exacerbation of chronic obstructive pulmonary disease in a rural tertiary care centre. $J$ Family Med Prim Care 2016; 5: 411-5.

15. Han MK, Postma D, Mannino DM et al. Gendre and chronic obstructive pulmonary disease- why it matters. Am J Resp Crit Care Med 2007; 176: 117984.

16. Badaran E, Ortega E, Bujalance C, Del Puerto L, Torres M, Antonio Riesco J. Smoking and COPD exacerbations. Euro Resp J 2012; 40: 1055.

17. Kaushal M, Shah PS, Shah AD, Francis SA, Patel NV, Kothari KK. Chronic obstructive pulmonary disease and cardiac comorbidities: A cross-sectional study. Lung India 2016; 33: 404-9. 
18. Boyer D, Artaud-Macari E, Schleifer D et al. Acute cor pulmonale during acute exacerbations of COPD: a new phenotype? Euro Resp J 2018; 52: 736.

19. Sarkar N, Rajta PN, Khatana J. Anemia in chronic obstructive pulmonary disease: prevalence, pathogenesis, and potential impact. Lung India 2015; 32: 142- 51.

20. Park SC, Kim YS, Kang YA et al. Hemoglobin and mortality in patients with COPD: a nationwide population- based cohort study. Int'l J COPD 2018; 13: 1599-605 .

21. Toft-Peterson AP, Torp-Pederson C, Weinreich UM, Rasmussen BS. Association between hemoglobin and prognosis in patients admitted to hospital for COPD. Int'l J COPD 2016; 11: 2813-20.

22. Alkady O, Fattouh M. Role of inflammatory biomarkers in COPD. Euro Resp J 2016; 48: 1010.

23. Biljak VR, Pancirov D, Cepelak I, Popovic Grle S, Stjepanovic G, Grubisic TZ. Platelet count, mean platelet volume and smoking status in stable chronic obstructive pulmonary disease. Platelets 2011; 22: 466-70.

24. Fawzy A, Putcha N, Paulin LM. Association of thrombocytosis with COPD morbidity: the
SPIROMICS and COPD gene cohorts. Respir Res 2018; 19: 20.

25. Skoczynski S, Krzyzak D, Studnicka A et al. Chronic obstructive pulmonary disease and platelet count. Adv Exp Med Biol 2019; 1160: 19-23.

26. Wang RT, Li JY. Cao ZG, Li Y. Mean platelet volume is decreased during an acute exacerbation of chronic obstructive pulmonary disease. Respirology 2013; 18: $1244-8$.

27. Ulasli SS, Ozyurek BA, Yilmaz EB, Ulubay G. Mean platelet volume as an inflammatory marker in acute exacerbation of chronic obstructive pulmonary disease. Pol Arch Med Wewn 2012; 122: 284-90.

28. Helmy TA, Baess AI, Algarahi AA. Mean platelet volume as an inflammatory marker in acute exacerbation of chronic obstructive pulmonary disease. Egypt J Broncho 2016; 10: 46-51.

29. Ozgul G, Seyhan EC, Ozgul MA, Gunluoglu MZ. Red blood cell distribution width in patients with chronic obstructive pulmonary disease and healthy subjects. Arch Bronconeumol 2017; 53: 107-13. 